\title{
PERFORMANCE OF TWO AMAN RICE VARIETIES USING VARYING PLANT DENSITY IN THE NORTHEASTERN REGION OF BANGLADESH
}

\author{
F. Ahmed ${ }^{1}$, M.N. Islam ${ }^{2}$ and M.H.M.B. Bhuyan ${ }^{1}$ \\ ${ }^{1}$ Citrus Research Station, Bangladesh Agricultural Research Institute, Jaintapur, Sylhet 3156, Bangladesh \\ ${ }^{2}$ Departments of Agronomy, Sylhet Agricultural University, Tillagorh, Sylhet-3100, Bangladesh \\ Corresponding E-mail: faisal.ag.sau@gmail.com
}

(Received: 03June 2021, Accepted: 29August 2021)

Keywords: Aromatic rice, spacing, panicle, yield, harvest index

\begin{abstract}
The experiment was conducted to assess the performance of two popular rice varieties with varying spacing at a farmer's field in Darbost union of Jaintapur Upazila under the Sylhet district of Bangladesh during aman season 2016. Two aman rice varieties (BRRI dhan34 and Binadhan-17), and four levels of plant density $(15 \times 10 \mathrm{~cm}, 20 \times 10 \mathrm{~cm}, 20 \times 15$ $\mathrm{cm}$, and $25 \times 15 \mathrm{~cm}$ ) were tested in a factorial randomized complete block design (RCBD) with three replications. The results indicated that yield and yield attributes of rice differed significantly due to varieties, spacing, and their interaction. It was recorded that var. Binadhan-17 showed maximum flag leaf length $(34.33 \mathrm{~cm})$, maximum number of filled grains $\mathrm{m}^{-2}$ (27855), maximum grain weight $\mathrm{m}^{-2}$ (654.58) contributed to increase grain yield $\left(6.55 \mathrm{t} \mathrm{ha}^{-1}\right)$ in closer spacing $(20 \times 10 \mathrm{~cm})$, which ultimately increased grain yield. Therefore, the results of the present study suggested that rice var. Binadhan-17 could be transplanted at $20 \times 10 \mathrm{~cm}$ spacing for getting maximum yield $\left(6.55 \mathrm{t} \mathrm{ha}^{-1}\right)$ in northeastern region of Bangladesh.
\end{abstract}

\section{Introduction}

In Bangladesh, approximately 11.61 million hectares land is under rice cultivation and producing 36.28 million tons (BBS, 2019). In 2018-19, the country acquired a rice surplus of about 2 MT (BBS, 2019). Therefore, exporting rice from the current surplus as well as maintaining the productivity and quality is a great challenge for the rice growers in the coming decades, where the high yielding could be an option.

The aromatic rice is known for its quality, fragrance, and demand in the domestic as well as international markets (Bajpai and Singh, 2010). But the fact is that farmers preferred coarse and medium rice varieties, whereas a minimal land space is covered by the fine and aromatic rice varieties (Bajpai and Singh, 2010). Due to a higher price, the aromatic rice is gaining popularity in Bangladesh. Some locally adapted varieties like Chinigura, Kalizira, and Kataribhog, etc. are covering rice-growing areas. Bangladesh Rice Research Institute (BRRI) and Bangladesh Institute of Nuclear Agriculture (BINA) has released some high yielder aromatic rice varieties like BRRI dhan34 and Binadhan-17 for the aman season.

Although the average yield per unit area increased, but, there is a wide yield gap between farmers' fields and on- station research results. This yield gap could be attributed to either the endogenous drivers, like genetic makeup and agronomic practices (Imade et al., 2015) or exogenous forces like climatic condition, which affects the genetic capability (Lesk et al., 2016). 
Some previous reports suggested that, a suitable variety is an important key to produce a higher return, together with a proper spacing, which plays a vital role in increasing growth development and yield of a specific rice variety to a great extent (Rahman et al., 2007; Thakur et al., 2009; Bozorgi et al., 2011). A sufficient spacing increases the performance of individual plants, while improper spacing reduced yield up to 20-30\% (IRRI, 1997). An optimum spacing ensures proficient exploitation of solar radiation and nutrients (Mohaddesi et al., 2011). In contrast, beyond the optimum level, severe competitions (for light, nutrients, and water) slow down plant growth and decrease grain yield (Bozorgi et al., 2011). Considering these facts, the study was carried out with the objectives to find out the variety specific spacing for maximizing yield and yield contributing characters of transplanted Aman rice.

\section{Materials and Methods}

\section{Experimental site and climatic conditions}

The experiment was conducted at a farmer's field at Darbost union of JaintapurUpazila, Sylhet. The geographical location of the experimental plot lies between $24^{\circ} 59^{\prime}$ and $25^{\circ} 11^{\prime}$ north latitudes and in between $92^{\circ} 03^{\prime}$ and $92^{\circ} 14^{\prime}$ east longitudes at an elevation of $30 \mathrm{~m}$ above the sea level. The experimental area was situated under sub-tropical climate, characterized by the heavy rainfall during Kharif season (April to September), and lower in Rabi season (October to March). The soil of the experimental site was sandy loam having medium fertility, belongs to the "Khadimnagar" series under eastern SurmaKushiyara floodplain (FRG,2012). The soil contains $1.45 \%$ organic matter, $0.8 \%$ N, $0.07 \mathrm{~m} \mathrm{~mol} \mathrm{K,} 25$ $\mu \mathrm{g} \mathrm{P}$ and $10 \mu \mathrm{g} \mathrm{S}$ per 100 gof soil with a $\mathrm{pH}$ value of 5.0.

\section{Experimental treatments and design}

The experiment included two factors, factor A-two varieties viz. BRRI dhan34 $\left(\mathrm{V}_{1}\right)$ and Binadhan-17 $\left(\mathrm{V}_{2}\right)$, and factor B- four spacing viz. $15 \times 10 \mathrm{~cm}\left(\mathrm{~S}_{1}\right), 20 \times 10 \mathrm{~cm}\left(\mathrm{~S}_{2}\right), 20 \times 15 \mathrm{~cm}\left(\mathrm{~S}_{3}\right), 25 \times 15 \mathrm{~cm}\left(\mathrm{~S}_{4}\right)$; laid out in a factorial randomized complete block design (RCBD factorial) with three replications.

\section{Input use and intercultural operations}

A piece of land was selected as nursery bed for raising seedlings. The experimental field was ploughed with a power tiller. Weeds, stubbles and residues were removed and cleaned from the field. Ploughing and cross ploughing was done thrice followed by laddering to prepare the land. The recommended fertilizers dose was $\mathrm{N}_{80} \mathrm{P}_{30} \mathrm{~K}_{40} \mathrm{~S}_{10} \mathrm{Zn}_{25}$ ha ${ }^{-1}$ according to SRDI, Sylhet. One third of the urea and the whole amount of triple super phosphate (TSP), muriate of potash (MoP), gypsum and zinc sulfate were applied as basal dose at the time of final land preparation and thoroughly incorporated into the soil. After uprooting the seedlings were similar sized 23 days old seedlings transplanted at the rate of three seedlings hill ${ }^{-1}$ maintaining spacing as per treatments. The rest of the urea fertilizer was applied in two equal splits; one at the maximum vegetative growth stage at 30 days after transplanting (DAT), and another at 45 DAT before panicle initiation stage. Weeding was done at 30 DAT in order to keep the crop weed free. Irrigation water was applied during the cropping season as when necessary. Plant protection measures were done as per requirements.

\section{Sampling, harvesting and processing}

Hills from the middle portion $(1 \times 1 \mathrm{~m})$ of each unit plot excluding border rows were randomly selected soon after transplanting and marked with bamboo sticks for determining growth parameters as well as yield and yield components. The crop was harvested at full maturity confirming $80 \%$ golden yellow colored grains. After harvested the sampled area the crop of each plot was separately bundled, properly tagged and then brought to the threshing floor. After drying, the grains $14 \%$ moisture level was confirmed in the grains. The straws are also sun dried. 


\section{Data measurements}

The data on the plant height, flag leaf length, panicle length, the number of panicles, productive tillers and ineffective tillers were collected before harvesting. The data on filled, empty grain was counted from randomly selected 20 panicles from different random hills. Thousands grain weight, grain yield, and straw yield were measured by an electric balance after the drying process.

Harvest index is basically the ratio of grain yield to total above ground biomass. Finally harvest index was calculated according to the following equation (Karki et al., 2018).

Harvest index $(\%)=\frac{\text { Grain yield }}{\text { Above ground biomass }} \times 100$

\section{Statistical Analysis}

The recorded data were compiled and analyzed statistically using Statix 10 computer package program and the analysis of variance were separated for significant difference by LSD test at $5 \%$ level of probability.

\section{Results and Discussion}

\section{Effect of spacing on growth parameters of rice varieties}

Significant variations were observed between two varieties, BRRI dhan34 attains maximum plant height $(126.08 \mathrm{~cm})$ whereas Binadhan-17 was shorter $(81.83 \mathrm{~cm})$. (Table 1). Similarly, plant spacing influences the plant height significantly. Among the four spacing; tallest plant $(111.50 \mathrm{~cm})$ was recorded at $15 \times 10 \mathrm{~cm}$ spacing, while, the shortest plant $(94.50 \mathrm{~cm}$ ) from $25 \times 15 \mathrm{~cm}$ spacing (Table 1). The combined effect of variety and spacing showed a significant variation where highest plant height $(135.00 \mathrm{~cm})$ was obtained from BRRI dhan 34 planted at $15 \times 10 \mathrm{~cm}$ spacing.. Contrary the lower plant height $(75.67 \mathrm{~cm})$ was obtained when Binadhan-17 planted at widest spacing $(25 \times 15 \mathrm{~cm})$, which was statistically similar with Binadhan-17 $(80.33 \mathrm{~cm})$ planted at $20 \times 15 \mathrm{~cm}$ spacing

The flag leafof Binadhan-17 produced the longest flag leaf $(32.58 \mathrm{~cm})$ in comparison to BRRI dhan34 $(22.58 \mathrm{~cm})$ (Table 1). On the other hand, maximum flag leaf $(29.00 \mathrm{~cm})$ was observed at $20 \times 15 \mathrm{~cm}$ spacing, which was statistically similar with $20 \times 10 \mathrm{~cm}(28.83 \mathrm{~cm})$ and $15 \times 10 \mathrm{~cm}(26.83 \mathrm{~cm})$ spacing while, the shortest flag leaf $(25.67 \mathrm{~cm})$ at wider spacing $(25 \times 15 \mathrm{~cm})$ (Table 1). Maximum flag leaf length $(34.33 \mathrm{~cm})$ was recorded from Binadhan -17 planted at $20 \times 10 \mathrm{~cm}$ spacing. On the other hand shortest flag leaf $(19.67 \mathrm{~cm})$ was found from BRRI dhan34 planted in a spacing of $25 \times 15 \mathrm{~cm}$. Furthermore, grain yield is positively correlated to the length, width, and area of flag leaf (Rahman et al., 2013). In our study, BRRI dhan 34 produced the maximum flag leaf length at wider spacing $(20 \times 15$ $\mathrm{cm})$ but Binadhan-17 produced maximum flag leaf length at closer spacing $(20 \times 10 \mathrm{~cm})$, which might be attributed to the genetic makeup of the varieties.

Table 1. Individual effect of varieties and spacing on plant height, flag leaf length, panicle length and number of panicle $\mathrm{m}^{-2}$ of rice

\begin{tabular}{lcccc}
\hline Treatments & $\begin{array}{c}\text { Plant height } \\
(\mathrm{cm})\end{array}$ & $\begin{array}{c}\text { Flag leaf length } \\
(\mathrm{cm})\end{array}$ & $\begin{array}{c}\text { Panicle length } \\
(\mathrm{cm})\end{array}$ & $\begin{array}{c}\text { Panicle } \\
\left(\mathbf{N o . ~ m}^{-2}\right)\end{array}$ \\
\hline
\end{tabular}

Variety 


\begin{tabular}{ccccc} 
BRRI dhan34 & $126.08 \pm 3.69 \mathrm{a}$ & $22.58 \pm 0.80 \mathrm{~b}$ & $24.17 \pm 0.29 \mathrm{a}$ & $265.73 \pm 3.02 \mathrm{a}$ \\
Binadhan-17 & $81.83 \pm 2.75 \mathrm{~b}$ & $32.59 \pm 0.52 \mathrm{a}$ & $19.92 \pm 0.38 \mathrm{~b}$ & $265.95 \pm 3.53 \mathrm{a}$ \\
\hline LSD $(0.05)$ & 1.84 & 1.33 & 1.48 & 5.73 \\
\hline Spacing & $111.50 \pm 3.97 \mathrm{a}$ & $26.833 \pm 0.58 \mathrm{ab}$ & $23.00 \pm 1.73 \mathrm{a}$ & $334.00 \pm 4.58 \mathrm{a}$ \\
$15 \times 10 \mathrm{~cm}$ & $106.50 \pm 3.78 \mathrm{~b}$ & $28.833 \pm 0.29 \mathrm{a}$ & $22.00 \pm 1.00 \mathrm{a}$ & $311.67 \pm 3.82 \mathrm{~b}$ \\
$20 \times 10 \mathrm{~cm}$ & $103.33 \pm 1.90 \mathrm{~b}$ & $29.000 \pm 1.32 \mathrm{a}$ & $21.83 \pm 0.76 \mathrm{a}$ & $232.50 \pm 1.5 \mathrm{c}$ \\
$20 \times 15 \mathrm{~cm}$ & $94.50 \pm 2.65 \mathrm{c}$ & $25.667 \pm 1.44 \mathrm{~b}$ & $21.33 \pm 0.76 \mathrm{a}$ & $185.20 \pm 1.83 \mathrm{~d}$ \\
$25 \times 15 \mathrm{~cm}$ & 3.52 & 2.55 & 2.83 & 10.98 \\
\hline $\operatorname{LSD}_{(0.05)}$ & &
\end{tabular}

Means with dissimilar letters are significantly different at $\mathrm{P} \leq 0.05$ at $\mathrm{LSD}$ test.

Both maximum number of paniclesm ${ }^{-2}(265.95)$ and length of panicles were also high $(24.17 \mathrm{~cm})$ in Binadhan-17 compared to BRRI dhan34 (265.73) and (19.92cm), respectively (Table 1). Notably, panicle length was not affected due to varied spacing, whereas, maximum number of panicle (334.00) was recorded at $15 \times 10 \mathrm{~cm}$ spacing, where the lowest $(185.20)$ at the wider spacing $(25 \times 15 \mathrm{~cm})($ Table 1). Moreover, BRRI dhan 34 produced the longest panicle $(25.33 \mathrm{~cm})$ when grown under $15 \times 10 \mathrm{~cm}$ spacing, while Binadhan-17 at $20 \times 15 \mathrm{~cm}$ and $25 \times 15 \mathrm{~cm}$ spacing produced the shortest panicle $(19.33 \mathrm{~cm})$.Combined effect of variety and spacing also showed that Binadhan-17 produced the highest number of panicles $\mathrm{m}^{-2}$ (336.00) when planted by $15 \times 10 \mathrm{~cm}$, which was similar to BRRI dhan34 (332.00) planted by $15 \times 10 \mathrm{~cm}$ spacing. On the other hand BRRI dhan34 planted $25 \times 15 \mathrm{~cm}$ spacing produced the lowest number of panicles $\mathrm{m}^{-2}$ (181.60) planted $25 \times 15 \mathrm{~cm}$ spacing, which was statistically similarto Binadhan-17 (188.80) planted $25 \times 15 \mathrm{~cm}$ spacing. On the other hand BRRI dhan34 produced longer panicle compared to Binadhan-17, which might be due to genetic makeup of the variety. Therefore, the result of our study corroborates with the findings of previous reports (Sarker, 2012; Ali et al., 2014; Hossain et al., 2014; Shiyam et al., 2014).

\section{Effect of spacing on yield attributes of rice varieties}

Both the varieties were indifferent regarding number of productive and infertile tillers hill ${ }^{-1}$. Binadhan17 produced higher number of productive tillers hill $^{-1}(6.84)$ but lower number of infertile tillers hill ${ }^{-1}$ (3.34). On the other hand BRRI dhan34 produced lower number of productive tillers hill ${ }^{-1}$ (6.79) but higher number of infertile tillers hill ${ }^{-1}$ (3.52) (Table 2). The maximum number of productive tillers $\operatorname{hill}^{-1}(7.75)$ was found at $20 \times 15 \mathrm{~cm}$ spacing followed by $25 \times 15 \mathrm{~cm}$ spacing $(7.72)$ and the lowest number of productive tillers hill ${ }^{-1}(5.57)$ at $15 \times 10 \mathrm{~cm}$ spacing. The result also shows that maximum number of sterile tillers hill ${ }^{-1}$ (4.30) was found at $15 \times 10 \mathrm{~cm}$ spacing followed by $20 \times 10 \mathrm{~cm}(3.97)$ spacing and the lowest number of sterile tillers hill ${ }^{-1}(2.58)$ at $25 \times 15 \mathrm{~cm}$ spacing (Table2). In case of interaction effects, Binadhan-17 recorded maximum number of productive tillers (7.87) planted $25 \times 15$ $\mathrm{cm}$ but was statistically at par with (7.80) planted $20 \times 15 \mathrm{~cm}$, and BRRI dhan34 (7.70) planted $20 \times 15 \mathrm{~cm}$. Contrary the lowest number of Effective tillers $(5.53$ was found at BRRI dhan34 planted $15 \times 10 \mathrm{~cm}$. Again, maximum number of infertile tillers (4.50) was recorded at BRRI dhan34 with 
$15 \times 10 \mathrm{~cm}$, which is statistically at par with Binadhan-17 (4.20) with $20 \times 10 \mathrm{~cm}$ and $15 \times 10 \mathrm{~cm}(4.10)$.

On the other side Binadhan-17 produced the lowest number of sterile tillers (2.33) with $20 \times 15 \mathrm{~cm}$.
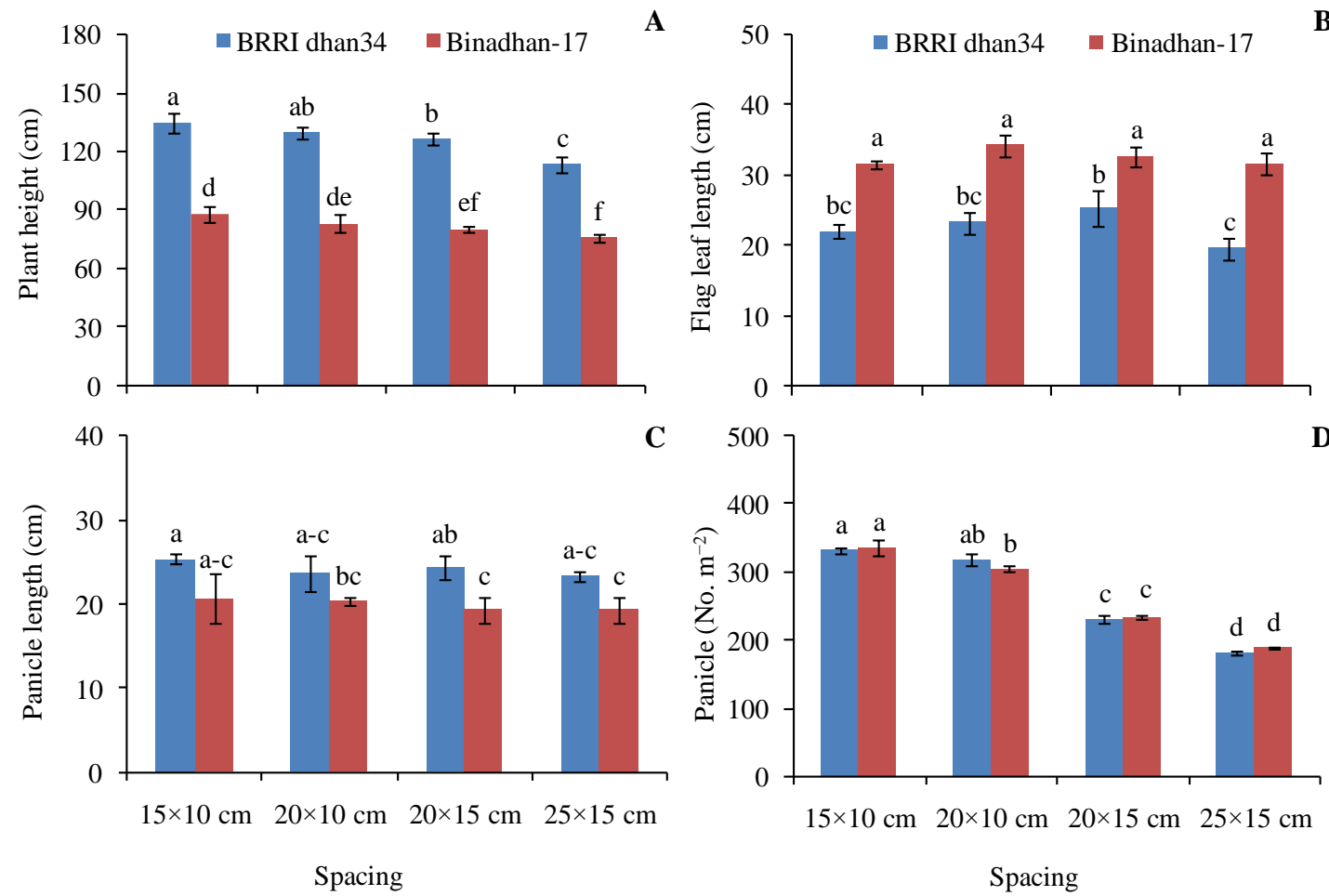

Fig.1. Combined effect of varieties and spacing on plant height, flag leaf length, panicle length and number of panicle $\mathrm{m}^{-2}$ of rice. Means with dissimilar letters are significantly different at $\mathrm{P} \leq$ 0.05 by LSD test.

Table 2. Individual effect of varieties and spacing on number of productive tillers $\mathrm{hill}^{-1}$, number of sterile tillers hill $^{-1}$, number of filled and empty grains panicle ${ }^{-1}$ of rice

\begin{tabular}{|c|c|c|c|c|}
\hline Treatments & $\begin{array}{l}\text { Effective tillers } \\
\left(\text { No. hill }{ }^{-1}\right)\end{array}$ & $\begin{array}{c}\text { Infertile tillers } \\
\left(\text { No. hill }{ }^{-1}\right)\end{array}$ & $\begin{array}{l}\text { Filled grains } \\
\text { (No. panicle }^{-1} \text { ) }\end{array}$ & $\begin{array}{c}\text { Empty grains } \\
(\text { No. hill } \\
\end{array}$ \\
\hline \multicolumn{5}{|l|}{ Variety } \\
\hline BRRI dhan34 & $6.79 \pm 0.07 \mathrm{a}$ & $3.53 \pm 0.07 \mathrm{a}$ & $71.42 \pm 1.23 b$ & $50.67 \pm 1.01 \mathrm{a}$ \\
\hline Binadhan-17 & $6.84 \pm 0.06 \mathrm{a}$ & $3.34 \pm 0.09 \mathrm{a}$ & $84.41 \pm 0.52 \mathrm{a}$ & $40.58 \pm 1.18 b$ \\
\hline $\operatorname{LSD}(0.05)$ & 0.13 & 0.21 & 2.51 & 2.75 \\
\hline \multicolumn{5}{|l|}{ Spacing } \\
\hline $15 \times 10 \mathrm{~cm}$ & $5.57 \pm 0.08 \mathrm{c}$ & $4.30 \pm 0.09 \mathrm{a}$ & $54.50 \pm 2.78 \mathrm{c}$ & $67.83 \pm 1.04 \mathrm{a}$ \\
\hline $20 \times 10 \mathrm{~cm}$ & $6.23 \pm 0.08 b$ & $3.97 \pm 1.76 \mathrm{a}$ & $76.00 \pm 0.5 b$ & $50.17 \pm 1.04 b$ \\
\hline $20 \times 15 \mathrm{~cm}$ & $7.75 \pm 0.05 \mathrm{a}$ & $2.88 \pm 1.19 b$ & $90.33 \pm 2.57 \mathrm{a}$ & $36.00 \pm 2.29 \mathrm{c}$ \\
\hline $25 \times 15 \mathrm{~cm}$ & $7.72 \pm 0.08 \mathrm{a}$ & $2.58 \pm 0.10 \mathrm{~b}$ & $90.83 \pm 2.84 \mathrm{a}$ & $28.50 \pm 2.78 \mathrm{~d}$ \\
\hline $\operatorname{LSD}(0.05)$ & 0.25 & 0.40 & 4.80 & 5.28 \\
\hline
\end{tabular}

Means with dissimilar letters are significantly different at $\mathrm{P} \leq 0.05$ by LSD test. 
Binadhan-17 produced higher number of filled grain panicle ${ }^{-1}(84.42)$ but lower number empty grain panicle $^{-1}$ (40.58). On the other hand lower number of filled grain panicle ${ }^{-1}$ (71.41) and higher number of empty grain panicle ${ }^{-1}$ (50.67) was recorded from BRRI dhan34 (Table 2). Maximum number of filled grain panicle ${ }^{-1}(90.83)$ was noticed at $25 \times 15 \mathrm{~cm}$ spacing, which was statistically similar with $20 \times 15 \mathrm{~cm}$ spacing (90.33), but the lowest number of filled grain panicle ${ }^{-1}(54.50)$ at $15 \times 10 \mathrm{~cm}$ spacing. Moreover, maximum number of empty grain hill $^{-1}(67.83)$ was recorded at $15 \times 10 \mathrm{~cm}$ spacing, while the lowest number of empty grain hill ${ }^{-1}(28.50)$ was recorded at $25 \times 15 \mathrm{~cm}$ spacing (Table 2).. The highest number filled grain (95.67) was obtained at Binadhan-17 with $20 \times 15 \mathrm{~cm}$ and $25 \times 15 \mathrm{~cm}$ but the lowest number of filled grain (54.00) with $15 \times 10 \mathrm{~cm}$. The interaction effect showed significant variation for empty grain. The highest no of empty grain (69.67) was recorded at Binadhan-17 with $15 \times 10 \mathrm{~cm}$, which is statistically similar with BRRI dhan34 (66.00) at $15 \times 10 \mathrm{~cm}$ and (65.00) at $20 \times 10$ $\mathrm{cm}$. On the other hand the lowest number of empty grain (23.00) was recorded at Binadhan-17 than with $25 \times 15 \mathrm{~cm}$. In case of Binadhan-17 did not found any variation regarding number of filled grains among $20 \times 10 \mathrm{~cm}, 20 \times 15 \mathrm{~cm}$ and $25 \times 15 \mathrm{~cm}$ of spacing, which might be due to the intrinsic capacity of this variety under the competitive condition for natural resources (water, nutrients, air and light). On the other hand number of empty grains increased drastically under closer spacing in BRRI dhan34. Sarker et al. (2002) found that under increased number of plants per unit area under closer spacing reduced the number of grains per panicle as well as increased the number of empty grains, which supports the results (Figure2).
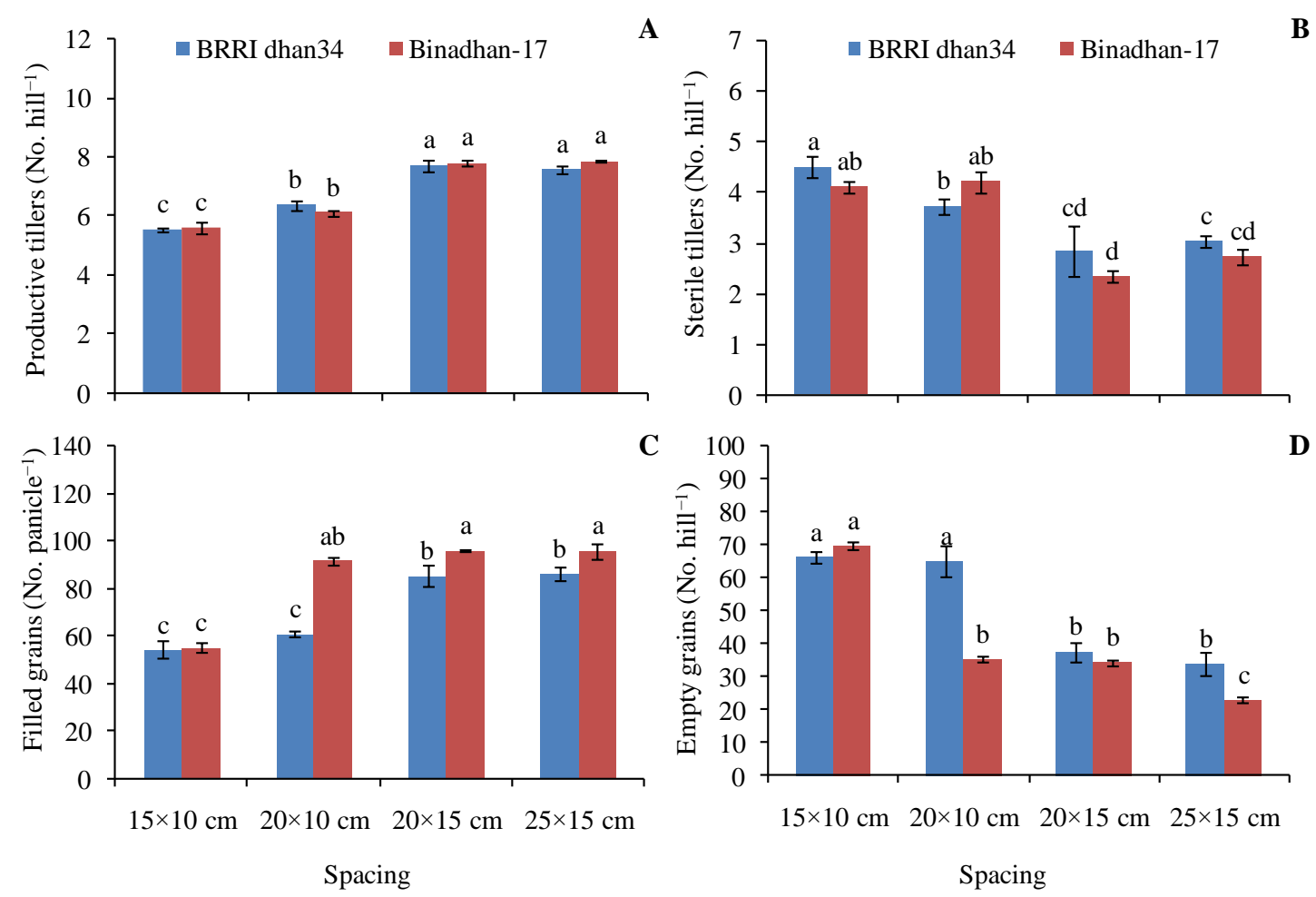

Spacing 
Fig. 2. Combined effect of varieties and spacing on number of productive tillers hill ${ }^{-1}$, number of sterile tillers hill ${ }^{-1}$, number of filled and empty grains panicle ${ }^{-1}$ of rice. Means with dissimilar letters are significantly different at $\mathrm{P} \leq 0.05$ by LSD test.

\section{Effect of spacing on grain weight, yield and harvest index of rice.}

Grain weight is one of the important factors for increasing rice grain yield (Huang et al., 2013). Thousands grain weight of any variety is dependent on both grain size and grain filling rate. Although grain size is regulated by genetic factors, grain filling rate is governed by the macro and micro climate of the field (Xie et al., 2015). Binadhan-17 had statistically heavier thousands grain weight (23.83) than BRRI dhan34 (17.32) (Table3).. The heavier thousands grain weight $(21.28 \mathrm{~g})$ was noticed at $25 \times 15 \mathrm{~cm}$ which is statistically similar with $20 \times 15 \mathrm{~cm}(21.23 \mathrm{~g})$ while lower thousands grain weight $(19.42 \mathrm{~g})$ at $15 \times 10 \mathrm{~cm}$ (Table 3). Binadhan-17 produces the same thousands grain weight $(24.80 \mathrm{~g})$ at $20 \times 15 \mathrm{~cm}$ and $25 \times 15 \mathrm{~cm}$. On the other hand, BRRI dhan34 produces the lower thousands grain weight $(16.63 \mathrm{~g})$ at $15 \times 10 \mathrm{~cm}$.

Rice grain yield depended on the length and number of panicles, number of fertile and sterile tillers, number of filled and empty grains per panicle as well as thousand grain weights (Melkie and Takele, 2020). Varieties had significant effect on grain yield. Binadhan-17 produced statistically higher grain yield $\left(5.17 \mathrm{t} \mathrm{ha}^{-1}\right)$ than BRRI dhan34 (3.14 $\left.\mathrm{t} \mathrm{ha}^{-1}\right)$ (Table 3). It was found that spacing had significant effect on grain yield. The highest grain yield $\left(4.93 \mathrm{t} \mathrm{ha}^{-1}\right)$ was found at $20 \times 10 \mathrm{~cm}$ followed by $20 \times 15$ $\mathrm{cm}\left(4.51 \mathrm{t} \mathrm{ha}^{-1}\right)$ and the lowest grain yield $\left(3.54 \mathrm{t} \mathrm{ha}^{-1}\right)$ at $15 \times 10 \mathrm{~cm}$. (Table3). The interaction effect showed significant variation grain yield.Binadhan-17 produced maximum grain yield $\left(6.55 \mathrm{t} \mathrm{ha}^{-1}\right)$ with $20 \times 10 \mathrm{~cm}$ followed by $20 \times 15 \mathrm{~cm}\left(5.55 \mathrm{t} \mathrm{ha}^{-1}\right)$ and the lowest grain yield $\left(4.10 \mathrm{t} \mathrm{ha}^{-1}\right)$ at $15 \times 10 \mathrm{~cm}$. On the other side, BRRI dhan 34 produced maximum grain yield $\left(3.47 \mathrm{t} \mathrm{ha}^{-1}\right)$ with $20 \times 15 \mathrm{~cm}$ followed by $20 \times 10 \mathrm{~cm}\left(3.32 \mathrm{t} \mathrm{ha}^{-1}\right)$ and the lowest grain yield $\left(2.77 \mathrm{t} \mathrm{ha}^{-1}\right)$ with $25 \times 15 \mathrm{~cm}$. Grain yield was significantly influenced by varieties and spacing. Binadhan- 17 produced maximum grain yield at closer spacing $(20 \times 10 \mathrm{~cm})$ but BRRI dhan34 produced maximum grain yield at wider spacing $(20 \times 15 \mathrm{~cm})$. In wider spacing $(20 \times 15 \mathrm{~cm})$ flag leaf length is maximum, maximum number of effective tiller hill ${ }^{-1}$, least number of sterile tillers hill ${ }^{-1}$, maximum number of filled grains $\mathrm{m}^{-2}$ contributed to increase grain weight $\mathrm{m}^{-2}$, which ultimately increased grain yield of BRRI dhan34. Similar findings were also obtained by other researchers, who reported that an increased number of effective tillers hill ${ }^{-1}$, as well as higher number of grains panicle ${ }^{-1}$ increased grain yield ha ${ }^{-1}$ (Uddin et al., 2011, Shiyam et al., 2014). On the other hand Binadhan-17 achieved significantly maximum flag leaf length, maximum number of filled grains $\mathrm{m}^{-2}$, maximum grain weight $\mathrm{m}^{-2}$, helped to increase grain yield in closer spacing $(20 \times 10 \mathrm{~cm})$. Similar finding had also been reported by Bhowmick and Nayak (2000) and Boling et al. (2004)(Figure 3).

Table 3. Individual effect of varieties and spacing on thousands grain weight, grain and straw yield $\mathrm{ha}^{-1}$, and harvest index of rice

\begin{tabular}{lcccc}
\hline Treatments & $\begin{array}{c}\text { Thousands } \\
\text { grain weight }(\mathbf{g})\end{array}$ & $\begin{array}{c}\text { Grain yield } \\
\left(\mathbf{t ~ h a}^{-\mathbf{1}}\right)\end{array}$ & $\begin{array}{c}\text { Straw } \mathbf{~} \\
\left(\mathbf{t ~ h a}^{-\mathbf{1}}\right)\end{array}$ & $\begin{array}{c}\text { Harvest index } \\
(\mathbf{\%})\end{array}$ \\
\hline Variety & & & & \\
BRRI dhan34 & $17.32 \pm 0.52 \mathrm{~b}$ & $3.1357 \pm 0.08 \mathrm{~b}$ & $4.7350 \pm 0.13 \mathrm{~b}$ & $39.818 \pm 0.14 \mathrm{~b}$ \\
Binadhan-17 & $23.83 \pm 0.04 \mathrm{a}$ & $5.1691 \pm 0.04 \mathrm{a}$ & $7.0731 \pm 0.06 \mathrm{a}$ & $42.097 \pm 0.02 \mathrm{a}$ \\
\hline LSD $(0.05)$ & 0.12 & 0.11 & 0.19 & 0.30 \\
\hline
\end{tabular}

Spacing 


\begin{tabular}{ccccc}
$15 \times 10 \mathrm{~cm}$ & $19.42 \pm 0.03 \mathrm{c}$ & $3.5408 \pm 0.11 \mathrm{c}$ & $5.3882 \pm 0.22 \mathrm{c}$ & $39.480 \pm 0.23 \mathrm{~d}$ \\
$20 \times 10 \mathrm{~cm}$ & $20.35 \pm 0.09 \mathrm{~b}$ & $4.9334 \pm 0.04 \mathrm{a}$ & $6.8551 \pm 0.08 \mathrm{a}$ & $41.296 \pm 0.22 \mathrm{~b}$ \\
$20 \times 15 \mathrm{~cm}$ & $21.23 \pm 0.03 \mathrm{a}$ & $4.5089 \pm 0.11 \mathrm{~b}$ & $6.1342 \pm 0.18 \mathrm{~b}$ & $42.415 \pm 0.32 \mathrm{a}$ \\
$25 \times 15 \mathrm{~cm}$ & $21.28 \pm 0.03 \mathrm{a}$ & $3.6266 \pm 0.09 \mathrm{c}$ & $5.2387 \pm 0.13 \mathrm{c}$ & $40.639 \pm 0.04 \mathrm{c}$ \\
\hline LSD $(0.05)$ & 0.24 & 0.21 & 0.36 & 0.57 \\
\hline
\end{tabular}

Means with dissimilar letters are significantly different at $\mathrm{P} \leq 0.05$ by LSD test.

The variety Binadhan -17 produced highest straw yield $\left(7.07 \mathrm{t} \mathrm{ha}^{-1}\right)$ whereas BRRI dhan 34 produced straw yield of $4.74 \mathrm{t} \mathrm{ha}^{-1}$ (Table 3).Spacing was also significantly influenced by straw yield. The highest straw yield $\left(6.86 \mathrm{t} \mathrm{ha}^{-1}\right)$ was found at $20 \times 10 \mathrm{~cm}$ followed by $20 \times 15 \mathrm{~cm}\left(6.13 \mathrm{t} \mathrm{ha}^{-1}\right)$ and the lowest straw yield $\left(5.24 \mathrm{t} \mathrm{ha}^{-1}\right)$ at $25 \times 15 \mathrm{~cm}$. (Table 3). The interaction effect showed significant variation on straw yield. The maximum straw yield $\left(8.58 \mathrm{t} \mathrm{ha}^{-1}\right)$ was recorded at Binadhan-17 with $20 \times 10 \mathrm{~cm}$ followed by $20 \times 15 \mathrm{~cm}\left(7.60 \mathrm{t} \mathrm{ha}^{-1}\right)$ and the lowest straw yield $\left(5.91 \mathrm{t} \mathrm{ha}^{-1}\right)$ with $15 \times 10 \mathrm{~cm}$. On the other hand, BRRI dhan34 produced maximum straw yield $\left(5.13 \mathrm{t} \mathrm{ha}^{-1}\right)$ with $20 \times 10 \mathrm{~cm}$ followed by $15 \times 10 \mathrm{~cm}\left(4.87 \mathrm{t} \mathrm{ha}^{-1}\right)$ and $20 \times 15 \mathrm{~cm}\left(4.67 \mathrm{tha}^{-1}\right)$ but the lowest straw yield $\left(4.28 \mathrm{t} \mathrm{ha}^{-1}\right)$ with $25 \times 15 \mathrm{~cm}$. On the other hand Binadhan-17 produced higher amount of straw compared to BRRI dhan34 (Figure 3), which might be due to the genetic makeup of the variety that favored the production of maximum straw.
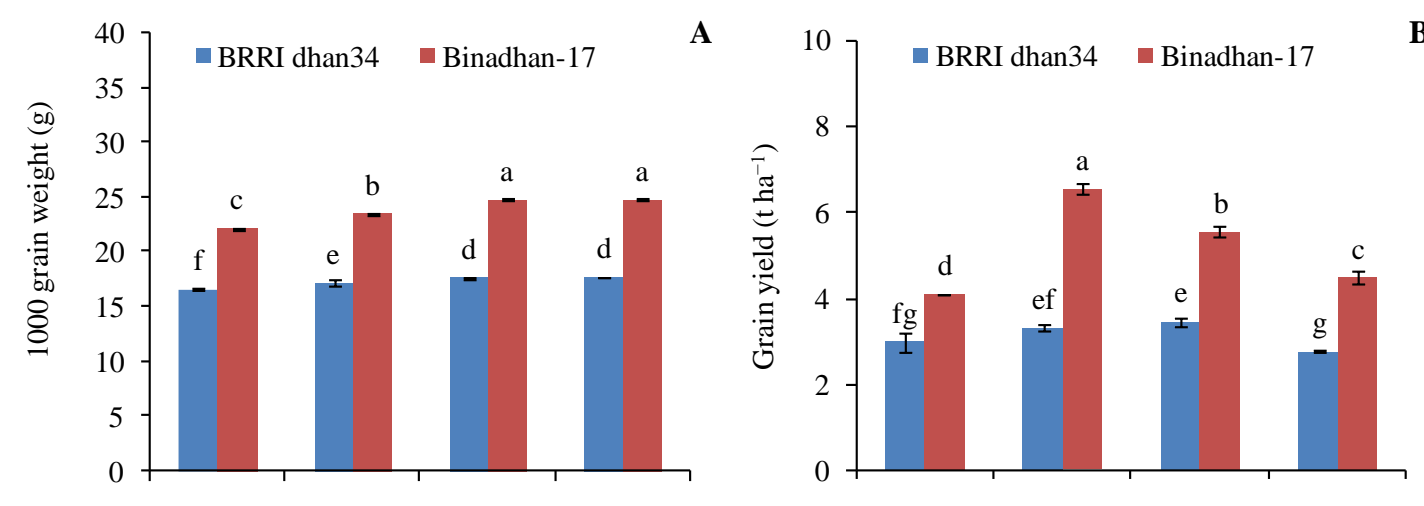

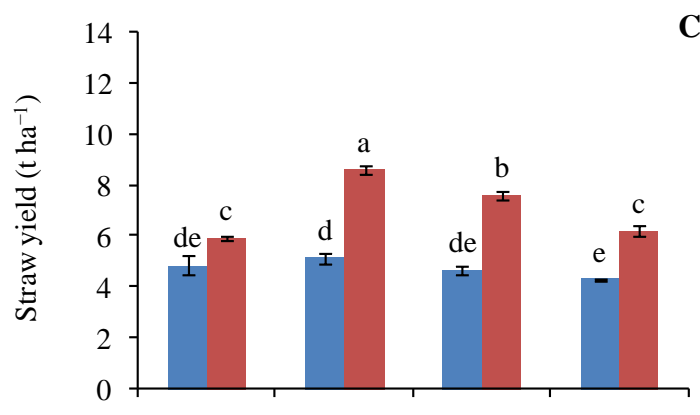

$15 \times 10 \mathrm{~cm} 20 \times 10 \mathrm{~cm} 20 \times 15 \mathrm{~cm} 25 \times 15 \mathrm{~cm}$ Spacing

C

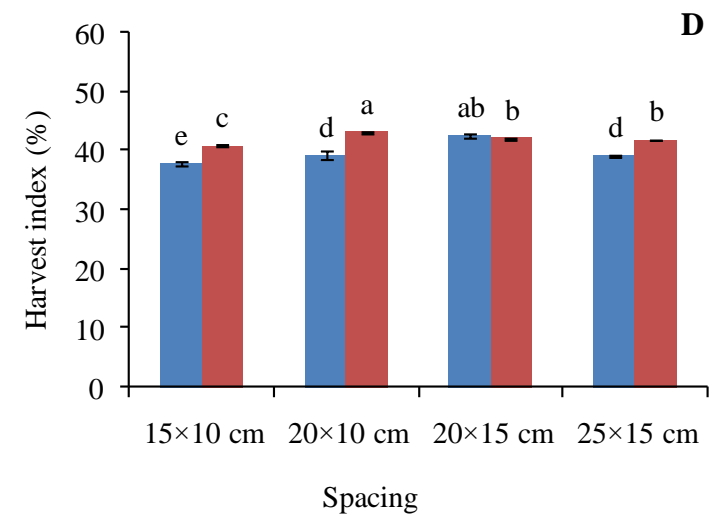


Fig. 3. Combined effect of varieties and spacing on thousands grain weight, grain and straw yield ha ${ }^{-1}$, and harvest index of rice. Means with dissimilar letters are significantly different at $\mathrm{P} \leq 0.05$ by LSD test.

The varieties with higher harvest index produced higher grain yield due to higher dry matter accumulation and partitioning into the panicles (Hay, 1995). Varieties showed significant influence on harvest index. Binadhan-17 gave higher harvest index (42.09) than BRRI dhan34 (39.82) (Table3). Maximum harvest index (42.42) was found at $20 \times 15 \mathrm{~cm}$ followed by $20 \times 10 \mathrm{~cm}(41.29)$ but the lowest harvest index (39.48) at $15 \times 10 \mathrm{~cm}$. (Table 3). Harvest index significantly affected by varieties and spacing. Binadhan-17 had the maximum harvest index (43.27) with $20 \times 10 \mathrm{~cm}$, which is statistically similar to BRRI dhan34 (42.62) with $20 \times 15 \mathrm{~cm}$. On the other side the lowest harvest index (38.01) was recorded at BRRI dhan34 with $15 \times 10 \mathrm{~cm}$. Moreover, the yield and harvest index differed due to genetic differences among varieties. Grain yield increases because of higher dry matter production due to maximum number of effective tillers, longest flag leaf length, maximum number of filled grain, as well as heavier grain weight. In general harvest index was higher in those rice varieties efficient in translocation of assimilates to the sink (grain) for higher economic yield (Alam et al., 2009)(Figure3).

\section{Conclusion}

From the study, it is revealed that both variety and plant density are important factors for better yield of Aman rice in north- eastern region of Bangladesh. The results showed that Binadahn-17 produced higher yield compared to BRRI dhan34. Among the plant density treatments $20 \times 10 \mathrm{~cm}$ and $20 \times 15 \mathrm{~cm}$ spacing showed better results in terms of yield contributing characters. The interaction effect showed that Binadahn-17 produced higher yield when grown under $20 \times 10 \mathrm{~cm}$ spacing, while BRRI dhan34 produced maximum yield with $20 \times 15 \mathrm{~cm}$ spacing. Therefore, it can be suggested t T.aman var. Binadhan-17 could be transplanted at $20 \times 10 \mathrm{~cm}$ spacing for getting maximum yield in northeastern region of Bangladesh.

\section{Acknowledgement}

The authors would like to acknowledge the Ministry of Science and Technology for financial support to conduct the research and Department of Agronomy and Haor Agriculture for providing facilities.

\section{References}

Agostinetto, D., M.A. Nohatto, C.P. Tarouco, J.J. Franco and E.D.F.F. da Rosa. 2018. Physiology of rice and red rice plants in competition for nitrogen. Científica 46(3):293-298.

Akter, N., E.Kayesh, M.M. Hossain and M.S.Alam. 2019. Morphological and physicochemical characterization of Burmese grape (Baccaurea ramiflora Lour.). Fundam. Appl. Agric. 4(2): 829838.

Alam, M.M., M.H. Ali, A.K.M.R. Amin and M. Hasanuzzaman. 2009. Yield attributes, yield and harvest index of three irrigated rice varieties under different levels of phosphorus. Adv. Biol. Re. 3:132139.

Ali, M.A., M.A. Sattar, M.N. Islam and K. Inubushi. 2014. Integrated effects of organic, inorganic and biological amendments on methane emission, soil quality and rice productivity in irrigated paddy 
ecosystem of Bangladesh: field study of two consecutive rice growing seasons. Plant Soil. 378: 239-252.

Anik, S.I. and M.A.S.A. Khan. 2012. Climate change adaptation through local knowledge in the north eastern region of Bangladesh. Mitig. Adapt. Strateg. Glob. Change. 17: 879-896.

Ashrafuzzaman, M., M.R. Islam, S.M. Shahidullah and M.M. Hanafi. 2009. Evaluation of six aromatic rice cultivars for yield and yield contributing characters. Int. J. Agric. Biol. 11:616-620.

Awan, T.H., R.I. Ali, Z. Manzoor, M. Ahmad and M. Akhtar. 2011. Effect of different nitrogen levels and row spacing on the performance of newly evolved medium grain rice variety, KSK-133. J. Anim. Plant Sci. 21: 231-234.

Bajpai, A. and Y. Singh. 2010. Study of quality characteristics of small and medium grained aromatic rice of Uttar Pradesh and Uttarakhand. Agric. Sci. Dig. 30: 241-245.

BBS. 2019. The Yearbook of Agricultural Statistics of Bangladesh. Bangladesh Bureau of Statistics, Statistics Division, Ministry of Planning, Government of the People's Republic of Bangladesh, Dhaka, Bangladesh, p.54.

Bezbaruha, R., R.C. Sharma, and P. Banik. 2011. Effect of nutrient management and planting geometry on productivity of hybrid rice (Oryza sativa L.) cultivars. Am. J. Plant Sci. 2: 297-302.

Bhowmick, N. and R.L. Nayak. 2000. Response of hybrid rice (Oryza sativa) varieties to nitrogen, phosphorus and potassium fertilizers during dry (boro) season in West Bengal. Indian J. Agron. 45: 323-326.

Bhowmik, S.K., M.A.R. Sarkar and F. Zaman. 2012. Effect of spacing and number of seedlings per hill on the performance of Aus rice cv. NERICA 1 under dry direct seeded rice (DDSR) system of cultivation. J. Bangladesh Agric. Univ. 10:191-195.

Biswas, B. 2008. Crop-weather-disease interaction in rice crop. M.Sc. Thesis. Punjab Agricultural University, Ludhiana, Punjab, India.

Boling, A., T.P. Tuong, S.Y. Jatmiko and M.A. Burac. 2004. Yield constraints of rainfed lowland rice in Central Java, Indonesia. Field Crop Res. 90: 351-360.

Bozorgi, H.R., A. Faraji and R.K. Danesh. 2011. Effect of plant density on yield and yield components of rice. World Appl. Sci. J. 12:2053-2057.

Donald, C.M. and J. Hamblin. 1976. The biological yield and harvest index of cereals as agronomic and plant breeding criteria. Adv. Agron. 28:361-405.

Fernandez, C.J., D.D. Fromme and W.J. Grichar. 2012. Grain sorghum response to row spacing and plant populations in the Texas coastal Bend region. Int. J. Agron. 238634. doi:10.1155/2012/238634.

FRG. 2012. Fertilizer recommendation guide. Bangladesh Agricultural Research Council (BARC), Dhaka, Bangladesh. p.27.

Garcia, G.A., M.F. Dreccer, D.J. Miralles and R.A. Serrago. 2015. High night temperatures during grain number determination reduce wheat and barleygrain yield: a field study. Glob. Chang. Biol. 21: 4153-4164.

Gunri, S.K., S.K. Pal and A. Chaudhury. 2004. Effect of integrated nitrogen application on yield of rice in foot hill soil of West Bengal. Indian J. Agron.49:248-250.

Hay, R.K.M. 1995. Harvest index: a review of its use in plant breeding and crop physiology. Ann. Appl. Biol. 126(1):197-216.

Hirooka, Y., K. Homma, T. Shiraiwa, Y. Makino, T.S. Liu, Z. Xu and L. Tang. 2018. Yield and growth characteristics of erect panicle type rice (Oryza sativa L.) cultivar, Shennong265 under various crop management practices in Western Japan. Plant Prod. Sci. 21: 1-7.

Hossain, M.M., F. Sultana and A.H.M.A. Rahman. 2014. A comparative screening of hybrid, modern cultivars and local rice cultivar for brown leaf spot disease susceptibility and yield performance. Arch. Phytopath. Plant Prot.47: 795-802.

Huang, R., L. Jiang, J. Zheng, T. Wang, H. Wang, Y. Huang and Z. Hong. 2013. Genetic bases of rice grain shape: so many genes, so little known. Trends Plant Sci. 18: 218-226. 
Imade, S.R., J.D. Thanki and N.N. Gudadhe. 2015. Integrated effect of organic manures and inorganic fertilizers on productivity, NPK uptake and profitability of transplanted rice. Res. Crops. 16: 401405.

IRRI. 1997. Rice Production Manual, International Rice Research Institute, UPLB, Los Banos, Philippines. p.95.

Ishfaq, M., N. Akbar, I. Khan, S.A. Anjum, U. Zulfiqar, M. Ahmad, M. Ahmad and M.U. Chattha.2018. Optimizing row spacing for direct seeded aerobic rice under dry and moist fields. Pak. J. Agric. Res. 31(4): 291-299.

Kandil, A.A., S.E. El-Kalla, A.T. Badawi and O.M. El-Shayb. 2010. Effect of hill spacing, nitrogen levels and harvest date on rice productivity and grain quality. Crop Environ. 1: 22-26.

Karki, S., N.S. Poudel, G. Bhusal, S. Simkhada, B.R. Regmi, B. Adhikari and S. Poudel. 2018. Growth parameter and yield attributes of rice (Oryza sativa) as influenced by different combination of nitrogen sources. World J. Agric. Res. 6:58-64.

Karmakar, B., M.A. Ali, M.A. Mazid, J. Duxbury and C.A. Meizner. 2004. Validation of system of rice intensification (SRI) practice through spacing, seedling age and water management. Bangladesh Agron. J. 10:13-21.

Khaliq, A., M.Y. Riaz and A. Matloob. 2011. Bio-economic assessment of chemical and non-chemical weed management strategies in dry seeded fine rice (Oryza sativa L.). Int. J.Plant Breed. Crop Sci. 3:302-310.

Khan, M.A.H., M.M. Alam, M.I. Hossain, M.H. Rashid, M.I.U. Mollah, M.A. Quddus, M.I.B. Miah, M.A.A. Sikder and J.K. Ladha. 2009. Validation and delivery of improved technologies in the rice-wheat ecosystem in Bangladesh. In: J.K. Ladha, Y. Sing, O. Erenstein, B. Hardy (eds.)Integrated crop and resource management in the rice-wheat system of South Asia. International Rice Research Institute, Los Banos, Philipine. pp.197-220.

Khush, G.S. 1993. Breeding Rice for Sustainable Agriculture Systems. In: D.R. Buxton, R. Shibles, R.A. Forsberg, B.L. Blad, K.H. Asay, G.M. Paulsen, R.F. Wilson (eds.) International Crop Science I. The Crop Science Society of America, Inc. Madison, Wisconsin, USA. pp.189-199.

Lesk, C., P. Rowhani and N. Ramankutty. 2016. Influence of extreme weather disasters on global crop production. Nature 529: 84-87.

Matusmoto, T., K.Yamada, Y. Yoshizawa and K.M. Oh.2016. Comparison of effect of brassinosteroid and gibberellin biosynthesis inhibitors on growth of rice seedlings. Rice Sci. 23:51-55.

Melkie, Z. and K.B.A. Takele. 2020. Effect of Nitrogen Fertilizer Levels and Row Spacing on Yield and Yield Components of Upland Rice Varieties in Pawe, Northwestern Ethiopia.J. Nat. Sci. Res. 10:112.

Mohaddesi, A., A. Abbasian, S. Bakhshipour and H. Aminpanah. 2011. Effect of different levels of nitrogen and plant spacing on yield, yield components and physiological indices in high-yield rice (number 843).American-Eurasian J. Agric. Enviro. Sci. 10: 893-900.

Montgomery, D.C. 2013. Design and Analysis of Experiments (Eighth edition). John Wiley \& Sons, Inc. Hovoken, NJ, USA.

Prasad, P.V.V., K.J. Boote, L.H. Allen Jr, J.E. Sheehy and J.M.G. Thomas. 2006. Species, ecotype and cultivar differences in spikelet fertility and harvest index of rice in response to high temperature stress. Field Crop Res. 95: 398-411.

Rahman, M.A., M.E. Haque, B. Sikdar, M.A. Islam and M.N. Matin. 2013. Correlation analysis of flag leaf with yield in several rice cultivars. J. Life Earth Sci. 8: 49-54.

Rahman, M.S., M.P. Anwar, M.M. Rahman, M.A. Islam and M.M. Rahman. 2007. Effect of spacing and weeding regime on the growth and yield of Aus rice.cv. BR26. Bangladesh J. Progressive Sci. Technol. 5(1):129-132.

Sarker, A.K. 2012. Effect of Cultivars and Nitrogen Level on Yield and Yield Performance of transplanted amanrice. M.S Thesis in Agronomy, Bangladesh Agricultural University, Mymensingh. p.25. 
Sarker, G., M. Rahman, R. Hasan and S.C. Roy. 2002. System of rice intensification: Yield and economic potential in boro rice at different locations of Bangladesh. LIFE-NOPEST project, CAREBangladesh. pp.1-5.

Sayeed, K.A. and Yunus, M.M. 2018. Rice prices and growth, and poverty reduction in Bangladesh. Food and Agriculture Organization of the United Nations. Background paper to the UNCTAD-FAO Commodities and Development Report 2017, Commodity Markets, Economic Growth and Development, Food and Agriculture Organization of the United Nations, Rome, Italy. pp.11-13.

Sharada, P. and P. Sujathamma. 2018. Effect of organic and inorganic fertilizers on the quantitative and qualitative parameters of rice (Oriza sativa L.). Current Agri. Res. 6: 12-19.

Shiyam, J.O., W.B. Binang and M.A. Ittah. 2014. Evaluation of growth and yield attributes of some lowland Chinese hybrid rice (Oryza sativa L.) cultivars in the Coastal Humid Forest Zone of Nigeria. IOSR J. Agric. Vet. Sci. 7(2): 70-73.

Singh, Y and U.S. Singh. 2008. Genetic diversity analysis in aromatic rice germplasm using agro morphological traits. J. Plant Genet. Resour. 21(1): 32-37.

Srinagar, K. 2012. Evaluation of plant spacing and seedlings per hill on rice (Oryza sativa L.) productivity under temperate conditions. Pak. J. Agri. Sci. 49(2): 169-172.

Surek, H and N. Beser. 2003. Correlation and path coefficient analysis for some yield-related traits in rice (Oryza sativa L.) under Thrace conditions. Turkey J. Agric. For. 27:77-83.

Thakur, A.K., S.K. Chaudhari, R. Singh and A. Kumar. 2009. Performance of rice cultivars at different spacing grown by the system of rice intensification in eastern India. Indian J. Agric. Sci. 79: 443447.

Tian, Y., H. Zhang, P. Xu, X. Chen, Y. Liao and B. Han. 2015. Genetic mapping of a QTL controlling leaf width and grain number in rice. Euphytica 202:1-11.

Uddin, M.J., S. Ahmed, H.M. Rashid, M.A. Hasan and M. Asaduzzaman. 2011. Effect of spacing on the yield and yield attributes of transplanted aman rice cultivars in medium lowland ecosystem of Bangladesh J. Agric. Res. 49(4): 465-476.

USDA. 2020. World Agricultural Production, Circular Series WAP 06-20. Foreign Agricultural Service, United States Department of Agriculture, Washington DC, USA. p.39.

Wang, D., J. Huang, L. Nie, F. Wang, X. Ling, K. Cui, Y. Li and S. Peng. 2017. Integrated crop management practices for maximizing grain yield of double-season rice crop. Sci. Rep. 7:38982. doi:10.1038/srep38982.

Xie, Q., S. Mayes and D.L. Sparkes. 2015. Carpel size, grain filling, and morphology determine individual grain weight in wheat. J. Exp. Bot. 66:6715-6730.

Xue, W., Y. Xing, X. Weng, Y. Zhao, W. Tang, L. Wang, H. Zhou, S.Yu, C. Xu, X. Li and Q. Zhang. 2008. Natural variation in Ghd7 is an important regulator of heading date and yield potential in rice. Nat. Genet. 40: 761-767.

Yu, H., Z. Qiu, Q. Xu, Z. Wang, D. Zeng, J. Hu, G. Zhang, L. Zhu, Z. Gao, G. Chen and L. Guo. 2017. Fine mapping of lowtiller 1, a gene controlling tillering and panicle branching in rice. Plant Growth Regul. 83: 93-104. 